This is the peer reviewed version of the following article: Vorotnikova, N. A., Edeleva, M. V., Kurskaya, O. G., Brylev, K. A., Shestopalov, A. M., Mironov, Y. V., Sutherland, A. J., Efremova, O. A. and Shestopalov, M. A. (2017), One-pot synthesis of \{Mo6/8\}4+-doped polystyrene microspheres via a free radical dispersion copolymerisation reaction. Polym. Int, 66: 19061912. doi:10.1002/pi.5473, which has been published in final form at http://onlinelibrary.wiley.com/doi/10.1002. This article may be used for non-commercial purposes in accordance with Wiley Terms and Conditions for Self-Archiving.

\title{
One-pot synthesis of $\left\{\mathrm{Mo}_{6} \mathrm{I}_{8}\right\}^{4+}$-doped polystyrene microspheres via a free-radical dispersion copolymerisation reaction
}

Natalya A. Vorotnikova, ${ }^{\mathrm{a}}$ Mariya V. Edeleva, ${ }^{\text {b,c }}$ Olga G. Kurskaya, ${ }^{\mathrm{d}}$ Konstantin A. Brylev, ${ }^{\mathrm{a}, \mathrm{c}}$ Alexander M. Shestopalov, ${ }^{\mathrm{d}}$ Yuri V. Mironov, ${ }^{\mathrm{a}, \mathrm{c}}$ Andrew J. Sutherland, ${ }^{e}$ Olga A. Efremova ${ }^{f^{*}}$ and Michael A. Shestopalove,

${ }^{a}$ Nikolaev Institute of Inorganic Chemistry SB RAS, 3 Acad. Lavrentiev Ave., 630090 Novosibirsk, Russian Federation, E-mail: shtopy@niic.nsc.ru

${ }^{b}$ Vorozhtsov Novosibirsk Institute of Organic Chemistry SB RAS, 9 Acad. Lavrentiev Ave, 630090 Novosibirsk, Russian Federation

'Novosibirsk State University, 2 Pirogova Str., 630090 Novosibirsk, Russian Federation

${ }^{d}$ Research Institute of Experimental and Clinical Medicine, 2 Timakova Str., 630060 Novosibirsk, Russian Federation

${ }^{e}$ Aston Institute of Materials Research, Aston University, Aston Triangle, Birmingham, B4 7ET, UK

fSchool of Mathematics and Physical Sciences, University of Hull, Cottingham Road, Hull, HU6 7RX, UK, E-mail: o.efremova@hull.ac.uk

\begin{abstract}
Molybdenum octahedral clusters, when incorporated into an appropriate polymer matrix, are considered as promising agents for a range of biological applications. This work describes the one-pot synthesis, morphology and cellular toxicity of nano-sized polystyrene beads doped by luminescent cluster complexes $\left[\left\{\mathrm{Mo}_{6} \mathrm{X}_{8}\right\}\left(\mathrm{NO}_{3}\right)_{6}\right]^{2-}(\mathrm{X}=\mathrm{Cl}, \mathrm{Br}$ or $\mathrm{I})$. Specifically, the particles were obtained by free-radical dispersion copolymerisation of styrene and methacrylic acid or 4-vinylpyridine in the presence of the cluster complex. The effect of the cluster loading in the reaction mixture on both the content of the final material and numberaverage molar mass of the copolymers were evaluated.
\end{abstract}

Keywords: Molybdenum cluster complex, free radical polymerisation, copolymer material, luminescence.

\section{Introduction}

Doping of conventional polymers such as poly(methyl methacrylate) (PMMA), poly $(N$ vinylcarbazole), polystyrene (PS), polyurethane, etc. by phosphorescent hexanuclear octahedral cluster complexes $\left[\left\{\mathrm{M}_{6} \mathrm{X}_{8}\right\} \mathrm{L}_{6}\right]^{m}$ (where $\mathrm{M}$ is $\mathrm{Mo}$ and $\mathrm{X}$ is $\mathrm{Cl}, \mathrm{Br}$ or I or $\mathrm{M}$ is Re and $\mathrm{X}$ is $\mathrm{S}$ or Se, while $\mathrm{L}$ is an apical ligand) has recently emerged as a simple and a convenient method to prepare new luminescence materials. ${ }^{1-14}$ These hybrid materials demonstrated potential for both 
This is the peer reviewed version of the following article: Vorotnikova, N. A., Edeleva, M. V., Kurskaya, O. G., Brylev, K. A., Shestopalov, A. M., Mironov, Y. V., Sutherland, A. J., Efremova, O. A. and Shestopalov, M. A. (2017), One-pot synthesis of \{Mo6/8\}4+-doped polystyrene microspheres via a free radical dispersion copolymerisation reaction. Polym. Int, 66: 19061912. doi:10.1002/pi.5473, which has been published in final form at http://onlinelibrary.wiley.com/doi/10.1002. This article may be used for non-commercial purposes in accordance with Wiley Terms and Conditions for Self-Archiving.

materials-based applications including fibrous materials for photonics and data transmission, ${ }^{1,2}$ polymer light-emitting diodes, ${ }^{3}$ oxygen sensing $^{4}$ and for biomedicine, e.g. as agents for optical bioimaging $^{5,}{ }^{6}$ (including $\mathrm{X}$-ray luminescence computed tomography ${ }^{7}$ ), photodynamic therapy and photoinactivation of bacteria. ${ }^{15}$

Among the whole family of hexanuclear metal-clusters, octahedral molybdenum cluster complexes are at the moment the most thoroughly studied moieties due to their outstandingly high photoluminescence quantum yields that can be achieved by careful selection of inner and apical ligands. ${ }^{11,16-21}$ Several routes were explored to incorporate these cluster complexes into organic matrices including (i) co-dissolution of metal clusters and polymers followed by solvent evaporation (often combined with processing into particles, films or fibres); ${ }^{11,12}$ (ii) free radical polymerisation of organic monomers with pre-made cluster complexes featuring vinyl-group functionality within their ligands or counter-ions $2,4,8,13$ and (iii) impregnation of cluster complexes, having labile apical ligands, into functionalised organic polymers. ${ }^{5,}$ 6, 14 Notably, any of these procedures usually employ at least two steps, such as synthesis of a bespoke (functionalised) polymer; synthesis of a bespoke (functionalised) metal cluster; doping of the polymer by the cluster and processing of the metal cluster/polymer hybrid.

To simplify the preparation of metal cluster-doped materials, in this work we sought to explore a one-pot procedure for the synthesis of molybdenum cluster-doped organic microparticles. Specifically, we report dispersion free-radical copolymerisation of styrene with functionalised monomers (methacrylic acid or 4-vinylpyridine) in the presence of molybdenum cluster complexes $\left[\left\{\mathrm{Mo}_{6} \mathrm{X}_{8}\right\}\left(\mathrm{NO}_{3}\right)_{6}\right]^{2-}(\mathrm{X}=\mathrm{Cl}, \mathrm{Br}, \mathrm{I})$ bearing labile apical $\mathrm{NO}_{3}$-ligands. The materials were obtained in the presence of varying amounts of clusters and the effect of the clusters on the morphology, final cluster loading and number-average molar mass of the resultant copolymer was evaluated.

Moreover, we also studied the cellular toxicity of the obtained micro-spheres using the larynx carcinoma (Hep-2) cell line as a model. Indeed these materials are particularly interesting in the context of in vitro bioimaging (for assay development and preliminary screening applications) and in vitro theranostic applications whereby imaging can be coupled with bead-mediated delivery. In the context of these applications, such inorganic clusters may be superior to conventional fluorophores and quantum dots. In contrast to metal clusters conventional fluorophores whilst widely used in many different labelling and imaging applications suffer from the very serious drawback of photobleaching. This phenomenon is problematic for all organic 
This is the peer reviewed version of the following article: Vorotnikova, N. A., Edeleva, M. V., Kurskaya, O. G., Brylev, K. A., Shestopalov, A. M., Mironov, Y. V., Sutherland, A. J., Efremova, O. A. and Shestopalov, M. A. (2017), One-pot synthesis of \{Mo6/8\}4+-doped polystyrene microspheres via a free radical dispersion copolymerisation reaction. Polym. Int, 66: 19061912. doi:10.1002/pi.5473, which has been published in final form at http://onlinelibrary.wiley.com/doi/10.1002. This article may be used for non-commercial purposes in accordance with Wiley Terms and Conditions for Self-Archiving.

molecule-based fluorophores and prevents imaging over extended time periods. ${ }^{22,} \quad 23$ Photobleaching is not a problem when imaging with the inorganic clusters or indeed with quantum dots. ${ }^{11,24,25}$ There are however toxicity issues associated with the use of quantum dots ${ }^{26}$ since they typically contain highly toxic materials (e.g. Cd, Se, Te, etc.) and even when coated (e.g. by liposomes, proteins, polymers etc.) which are reported to reduce toxicity ${ }^{27}$ they still remain toxic. In our other works ${ }^{6,14,28}$ as well as in the current work we demonstrate that octahedral molybdenum clusters have extremely low toxicity.

\section{Experimental}

\subsection{Equipment}

Fourier transform infrared spectroscopy (FTIR) was conducted on a Bruker Vertex 80 (Bruker Corporation, Billerica, MA, USA), with samples dispersed in $\mathrm{KBr}$ disks. Optical diffuse reflectance spectra were measured at room temperature on a Shimadzu UV-Vis-NIR 3101 PC spectrophotometer (Shimadzu Corporation, Kyoto, Japan) equipped with an integrating sphere and reproduced in the form of Kubelka-Munk theory. Atomic emission spectrometry with direct current arc was carried out on a spectrograph PGS-2 (Carl Zeiss Jena, Germany). The shape and size of the copolymer microparticles were characterized by Transmission Electron Microscopy (TEM) using a Libra 120 (Zeiss) TEM. Elemental maps were recorded using the standard threewindow technique described in Brydson, Electron Energy Loss Spectroscopy (Bios Scientific Publishers Ltd, 2001). GPC was carried out on an Agilent LC 1200 setup equipped with an isocratic pump, a PL-gel Mixed-C column, and a UV refractometric detector. The system, operating at $40{ }^{\circ} \mathrm{C}$ with an eluent (THF) flow rate of $1 \mathrm{~mL} \cdot \mathrm{min}^{-1}$, was calibrated against narrow polystyrene standards (Mp ranged from 162 to $6035000 \mathrm{~g} \cdot \mathrm{mol}^{-1}$ ). ${ }^{1} \mathrm{H}$ NMR spectra were recorded in $\mathrm{CDCl}_{3}\left(\delta_{\mathrm{H}}=7.26\right)$ in the standard way on Bruker Avance 200 spectrometer. The optical density for the MTT-assay was measured with a Multiskan FC (Thermo scientific, USA) plate reader at a wavelength of $620 \mathrm{~nm}$.

\subsection{Materials}

$\left(\mathrm{Bu}_{4} \mathrm{~N}\right)_{2}\left[\left\{\mathrm{Mo}_{6} \mathrm{X}_{8}\right\}\left(\mathrm{NO}_{3}\right)_{6}\right]\left(\mathrm{X}=\mathrm{Cl}, \mathrm{Br}\right.$ or I) clusters were synthesised as described previously. ${ }^{6}, 29$ Methacrylic acid (MAA), 4-vinylpyridine (4-ViPy), tert-butyl peroxybenzoate (Luperox ${ }^{\circledR} \mathrm{P}$ ), styrene and poly(vinylpyrrolidone) (PVP, $58 \mathrm{kDa}$ ) were purchased from Sigma Aldrich and used as received, with the exception of styrene where the inhibitors present in the monomer were 
This is the peer reviewed version of the following article: Vorotnikova, N. A., Edeleva, M. V., Kurskaya, O. G., Brylev, K. A., Shestopalov, A. M., Mironov, Y. V., Sutherland, A. J., Efremova, O. A. and Shestopalov, M. A. (2017), One-pot synthesis of \{Mo6/8\}4+-doped polystyrene microspheres via a free radical dispersion copolymerisation reaction. Polym. Int, 66: 19061912. doi:10.1002/pi.5473, which has been published in final form at http://onlinelibrary.wiley.com/doi/10.1002. This article may be used for non-commercial purposes in accordance with Wiley Terms and Conditions for Self-Archiving.

removed via extraction with $1 \mathrm{M} \mathrm{NaOH}$ solution and the monomer subsequently dried over $\mathrm{MgSO}_{4}$.

\subsubsection{General procedure for preparation of neat and cluster-doped polystyrene microparticles}

Microparticle samples denoted as $\left\{\mathrm{Mo}_{6} \mathrm{X}_{8}\right\}^{n} @ \mathrm{PS}-\mathrm{COOH}$ and $\left\{\mathrm{Mo}_{6} \mathrm{X}_{8}\right\}^{n} @ \mathrm{PS}-\mathrm{Py}$ (where $\mathrm{X}$ is $\mathrm{Cl}$, $\mathrm{Br}$ or $\mathrm{I} ; n$ is the loading of the initial cluster $\left(\mathrm{Bu}_{4} \mathrm{~N}\right)_{2}\left[\left\{\mathrm{Mo}_{6} \mathrm{X}_{8}\right\}\left(\mathrm{NO}_{3}\right)_{6}\right]$ in \%; neat PS-COOH or neat PS-Py is styrene copolymerised with $2 \% \mathrm{w} / \mathrm{w}$ of MAA or $4-\mathrm{ViPy}$, respectively) were prepared by dispersion copolymerisation using the following protocol: styrene $(1100 \mu \mathrm{L}, 9.6$ mmol), 10, 50 or $100 \mathrm{mg}$ of $\left(\mathrm{Bu}_{4} \mathrm{~N}\right)_{2}\left[\left\{\mathrm{Mo}_{6} \mathrm{X}_{8}\right\}\left(\mathrm{NO}_{3}\right)_{6}\right](1,5$ and $10 \% \mathrm{w} / \mathrm{w}$ with styrene), MAA (16.2 $\mu \mathrm{L}, 0.2 \mathrm{mmol})$ or 4-ViPy (20.4 $\mu \mathrm{L}, 0.2 \mathrm{mmol})$, and the initiator tert-butyl peroxybenzoate (18.3 $\mu \mathrm{L}, 0.096 \mathrm{mmol}$ ) were dissolved in $13 \mathrm{~mL}$ of a 1\% ethanolic solution of PVP. The solution was degassed with argon for 10 minutes and the reaction tube was sealed. The reaction mixture was stirred at $80{ }^{\circ} \mathrm{C}$ for $24 \mathrm{~h}$. After completion of the reaction, $5 \mathrm{~mL}$ of EtOH was added to the suspension to remove unreacted cluster complex and the mixture was stirred for 5 minutes and then centrifuged (6000 rpm for 8 minutes). The precipitate was rinsed once with EtOH (5 mL) and twice with $\mathrm{H}_{2} \mathrm{O}(5 \mathrm{~mL})$ and finally re-suspended in $5 \mathrm{~mL}$ of water. To estimate the dependence of molecular weight and monomer conversion on reaction time, $1 \mathrm{~mL}$ aliquots were collected 2, 4, 6, 21 and $24 \mathrm{~h}$ after initiation of the copolymerisation reaction.

\subsubsection{Conversion study}

The volatile components of the reaction mixture were removed by evaporation using the rotary evaporator. The residual mixture of PVP and polystyrene copolymer was dissolved in $0.6 \mathrm{~mL}$ of $\mathrm{CDCl}_{3}$. PVP was used as an internal standard to determine the amount of polystyrene formed. Specifically, the conversion of the copolymer was calculated using the formula: Conv(\%) $=\frac{I(6.0-6.73 \mathrm{ppm})}{I(2.8-4.0 \mathrm{ppm})} \times \frac{3}{5} \times \frac{n(\text { PVP })}{n(\text { styrene })} \times 100 \%$, where $\mathrm{I}(6.0-6.73 \mathrm{ppm})$ and $\mathrm{I}(2.8-4 \mathrm{ppm})$ are the integrated intensities of signals from polystyrene and PVP, respectively, while n(PVP) and $\mathrm{n}$ (styrene) are the number of moles of PVP and styrene used in the reaction (Figure 1S, ESI).

\subsection{Physico-chemical characterisation}

\subsubsection{Luminescence measurements}

To measure the emission properties of $\left\{\mathrm{Mo}_{6} \mathrm{X}_{8}\right\}^{1} @ \mathrm{PS}-\mathrm{COOH}$ and $\left\{\mathrm{Mo}_{6} \mathrm{X}_{8}\right\}^{1} @ \mathrm{PS}-\mathrm{Py}$ powders, the samples were placed between two non-fluorescent glass plates. The measurements were carried out at $298 \mathrm{~K}$. The samples were excited by 355-nm laser pulses (6 ns duration, LOTIS 
This is the peer reviewed version of the following article: Vorotnikova, N. A., Edeleva, M. V., Kurskaya, O. G., Brylev, K. A., Shestopalov, A. M., Mironov, Y. V., Sutherland, A. J., Efremova, O. A. and Shestopalov, M. A. (2017), One-pot synthesis of \{Mo6/8\}4+-doped polystyrene microspheres via a free radical dispersion copolymerisation reaction. Polym. Int, 66: 19061912. doi:10.1002/pi.5473, which has been published in final form at http://onlinelibrary.wiley.com/doi/10.1002. This article may be used for non-commercial purposes in accordance with Wiley Terms and Conditions for Self-Archiving.

TII, LS-2137/3). The corrected emission spectra were recorded on a red-light-sensitive multichannel photodetector (Hamamatsu Photonics, PMA-11). The emission decay was analysed by a streakscope system (Hamamatsu Photonics, C4334 and C5094). The emission quantum yields were determined on an Absolute Photo-Luminescence Quantum Yield Measurement System (Hamamatsu Photonics, C9920-03), which comprised of an excitation Xenon light source $\left(\lambda_{\mathrm{ex}}=400 \mathrm{~nm}\right)$, an integrating sphere and a red-sensitive multichannel photodetector (Hamamatsu Photonics, PMA-12).

\subsection{Biological studies}

\subsubsection{Cell proliferation colorimetric assay}

Human epidermoid larynx carcinoma (Hep-2) cells were purchased from the State Research Centre of Virology and Biotechnology VECTOR (Koltsovo, Novosibirsk region, Russian Federation) and cultured in Eagle's minimum essential medium supplemented with $10 \%$ fetal bovine serum, under a humidified atmosphere $\left(5 \% \mathrm{CO}_{2}\right.$ plus $95 \%$ air $)$ at $37{ }^{\circ} \mathrm{C}$.

The cells were seeded on a 96-well plate at a concentration of $7 \times 10^{3}$ cells per well and incubated at $37{ }^{\circ} \mathrm{C}$ and $5 \% \mathrm{CO}_{2}$ for 24 hours. The media was then replaced with fresh media and the cells were cultured for $48 \mathrm{~h}$ with suspensions of $\left\{\mathrm{Mo}_{6} \mathrm{I}_{8}\right\}^{1} @ \mathrm{PS}-\mathrm{COOH}$ or neat PS-COOH microbeads in a concentration range from 0.006 to $3.25 \mathrm{mg} / \mathrm{mL}$. The negative control was prepared identically but without any polymeric materials. $10 \mu \mathrm{L}$ of 3-(4,5-dimethylthiazol-2-yl)-2,5diphenyltetrazolium bromide (MTT) solution $(5 \mathrm{mg} / \mathrm{mL})$ and $90 \mu \mathrm{L}$ of media was added to each well, and the plates were incubated for $4 \mathrm{~h}$. Thereafter the culture media was removed, the formazan formed was dissolved in $150 \mu \mathrm{L}$ of dimethyl sulfoxide, vortexed, and the formazan concentration was determined spectrophotometrically at $620 \mathrm{~nm}$. The results are presented as the ratio of the optical density of the sample to the control. The experiment was repeated on three separate days.

\subsection{Statistical analyses}

Statistical analyses were performed using the Mann-Whitney $\mathrm{U}$ test for unpaired data and $\mathrm{P}$ values of less than 0.01 were considered as significant. The data are presented as mean \pm SEM (standard error of the mean).

\section{Results and discussion}

\subsection{Synthesis}


This is the peer reviewed version of the following article: Vorotnikova, N. A., Edeleva, M. V., Kurskaya, O. G., Brylev, K. A., Shestopalov, A. M., Mironov, Y. V., Sutherland, A. J., Efremova, O. A. and Shestopalov, M. A. (2017), One-pot synthesis of \{Mo6/8\}4+-doped polystyrene microspheres via a free radical dispersion copolymerisation reaction. Polym. Int, 66: 19061912. doi:10.1002/pi.5473, which has been published in final form at http://onlinelibrary.wiley.com/doi/10.1002. This article may be used for non-commercial purposes in accordance with Wiley Terms and Conditions for Self-Archiving.

Molybdenum cluster complexes demonstrate intense phosphorescence and an ability to generate singlet oxygen and therefore they have high potential for both materials-based (e.g. photonics materials) and biological applications (e.g. bioimaging and photodynamic therapy agents). To explore this potential, molybdenum clusters are often incorporated into pre-made polymer micro- and nano-particles functionalised by either $n$-donor groups, i.e. ligands for molybdenum atoms, ${ }^{5,6}$ or cationic groups to bind cluster anions by electrostatic forces. ${ }^{15}$ For example, we have recently reported utilisation of polystyrene microparticles functionalised by thiol groups as copolymeric ligands for $\left\{\mathrm{Mo}_{6} \mathrm{X}_{8}\right\}^{4+}$ cluster core, where complexes $\left(\mathrm{Bu}_{4} \mathrm{~N}\right)_{2}\left[\left\{\mathrm{Mo}_{6} \mathrm{X}_{8}\right\}\left(\mathrm{NO}_{3}\right)_{6}\right]$ ( $\mathrm{X}=\mathrm{Cl}, \mathrm{Br}$ or I) were used as precursors to produce luminescent polystyrene particles. ${ }^{5,6}$ The purity if the clusters were characterised by IR and CHN analysis (Figure 2S, Table 1S).

Polystyrene particles of sub-micron size are indeed of particular interest, since they have shown high efficiency for beadfection (i.e. cellular delivery using polymer beads ${ }^{30-32}$ ). Indeed earlier works ${ }^{31}$ have shown that one to two micron-sized microspheres are taken up readily by cells via a non-endocytosis mediated mechanism. This uptake mechanism is vital if one is to deliver fragile molecular cargoes such as proteins ${ }^{30}$ since it avoids exposure of the molecular cargo to the degradative environment of the endosome. Spherical polystyrene microbeads with narrow size distributions are easily obtained by dispersion polymerisation of styrene in droplets stabilised by a non-ionic surfactant, in particular PVP - poly( $N$-vinylpyrrolidone).$^{30}$ However, incorporation of a polar (more hydrophilic) functionalised monomer is often very challenging: as the amount of a hydrophilic monomer that can be copolymerised is limited regardless of the initial content, ${ }^{33-35}$ while incorporation of such a monomer can result in increased particle sizes and size distribution. ${ }^{36-38}$ On the other hand, a low concentration of the functionalised monomer within the particles limits the number of clusters that can be immobilised, since accessibility to a sufficient number of donor groups distributed within the microspheres can be difficult.

To facilitate easy access of metal cluster to functionalised moieties within the microspheres, here we have undertaken a one-pot dispersion copolymerisation of styrene with the polar functionalised monomers - methacrylic acid (MAA) and 4-vinylpyridine (4-ViPy) in the presence of $\left(\mathrm{Bu}_{4} \mathrm{~N}\right)_{2}\left[\left\{\mathrm{Mo}_{6} \mathrm{X}_{8}\right\}\left(\mathrm{NO}_{3}\right)_{6}\right]$ as a source of photoluminescent cluster core. Indeed, we have shown earlier that these complexes are highly labile, due to the presence of nitrato-ligands 5 , 6, 14 and therefore would undergo ligand metathesis with the functionalised moieties within the microspheres. To minimise the effect of the polar monomers on the morphology of the final 
This is the peer reviewed version of the following article: Vorotnikova, N. A., Edeleva, M. V., Kurskaya, O. G., Brylev, K. A., Shestopalov, A. M., Mironov, Y. V., Sutherland, A. J., Efremova, O. A. and Shestopalov, M. A. (2017), One-pot synthesis of \{Mo6/8\}4+-doped polystyrene microspheres via a free radical dispersion copolymerisation reaction. Polym. Int, 66: 19061912. doi:10.1002/pi.5473, which has been published in final form at http://onlinelibrary.wiley.com/doi/10.1002. This article may be used for non-commercial purposes in accordance with Wiley Terms and Conditions for Self-Archiving.

beaded hybrid material, their amount was set to 2\%-mol, while the amount of copolymerisation initiator (tert-butyl peroxybenzoate) was 1\%-mol.

To evaluate the effect of presence of molybdenum cluster on copolymerisation we studied the number-average molar mass $\left(M_{\mathrm{n}}\right)$ of the copolymers by GPC and monomer conversion by NMR spectrometry analysis on samples obtained in the presence of different amounts of the clusters $1 \%, 5 \%$ and $10 \% \mathrm{w} / \mathrm{w}$ with respect to styrene (Figure 1 ). The $M_{\mathrm{n}}$ and dispersity index $(\nexists)$ values of the samples of $\left\{\mathrm{Mo}_{6} \mathrm{X}_{8}\right\}^{n} @ \mathrm{PS}-\mathrm{COOH}$ and $\left\{\mathrm{Mo}_{6} \mathrm{X}_{8}\right\}^{n} @ \mathrm{PS}-\mathrm{Py}(\mathrm{X}=\mathrm{Cl}, \mathrm{Br}$ or I), neat PS$\mathrm{COOH}$ and neat PS-Py collected from the reaction mixture are presented in Figure 3S-11S while the data obtained after copolymerisation for $24 \mathrm{~h}$ are summarised in Table 1 . The data show that the molybdenum clusters inhibit the free radical copolymerisation reaction. Specifically, with increased cluster loading, both the monomer conversion and molecular weight of the copolymer decreases. Indeed, in the presence of $1 \%$ of any of the clusters after $24 \mathrm{~h}$ copolymerisation the overall monomer conversion was about $40-60 \%$ and the molecular weight of the resultant copolymer was up to $\sim 60 \mathrm{kDa}$, i.e. both were lower than that for the corresponding neat copolymer (110 kDa for PS-COOH and 77kDa for PS-Py with $80 \%$ or above of conversion). The presence of $10 \% \mathrm{w} / \mathrm{w}$ of any of the clusters significantly disrupts the copolymerisation reaction, as the final monomer conversion values were all no more than $20 \%$, while number-average molar masses were 0.6-3.7 $\mathrm{kDa}$ for samples with the chloride and iodide complexes and 10-21 $\mathrm{kDa}$ for samples with the bromide complex (Table 1). This observation signifies that the cluster acts as a copolymerisation inhibitor suppressing both the growth of copolymer chains and the amount of monomer conversion. Therefore, all the following characterisation were undertaken on samples prepared in the presence of $1 \%-\mathrm{w} / \mathrm{w}$ of cluster after copolymerisation for $24 \mathrm{~h}$.

The inhibition is likely due to some interactions of the molybdenum in the clusters with the initiator and/or forming radicals, which decelerates the growth of the copolymeric chain. 2, 39 Indeed, it is known that metal clusters can participate in electron-transfer processes producing radicals, which are less reactive than those formed in polymerisation reaction. ${ }^{19,40-43}$ Formation of such radicals means that clusters to act as copolymerisation inhibitors since they can effectively scavenge free radicals from the copolymerisation reaction thereby slowing it down or stopping it altogether. Notably, the presence of hexamolybdenum cluster complexes has been reported to have a similar effect on the number-average molar masses of other copolymers, although somewhat less pronounced: for example in the bulk and solution copolymerisation of methyl methacrylate in the presence of such labile complexes as $\left[\left\{\mathrm{Mo}_{6} \mathrm{I}_{8}\right\}\left(\mathrm{OT}_{\mathrm{S}}\right)_{6}\right]^{2-}$ and $\left[\left\{\mathrm{Mo}_{6} \mathrm{I}_{8}\right\}\left(\mathrm{CF}_{3} \mathrm{CF}_{2} \mathrm{COO}\right)_{6}\right]^{2-2,13}$ 
This is the peer reviewed version of the following article: Vorotnikova, N. A., Edeleva, M. V., Kurskaya, O. G., Brylev, K. A., Shestopalov, A. M., Mironov, Y. V., Sutherland, A. J., Efremova, O. A. and Shestopalov, M. A. (2017), One-pot synthesis of \{Mo6/8\}4+-doped polystyrene microspheres via a free radical dispersion copolymerisation reaction. Polym. Int, 66: 19061912. doi:10.1002/pi.5473, which has been published in final form at http://onlinelibrary.wiley.com/doi/10.1002. This article may be used for non-commercial purposes in accordance with Wiley Terms and Conditions for Self-Archiving.

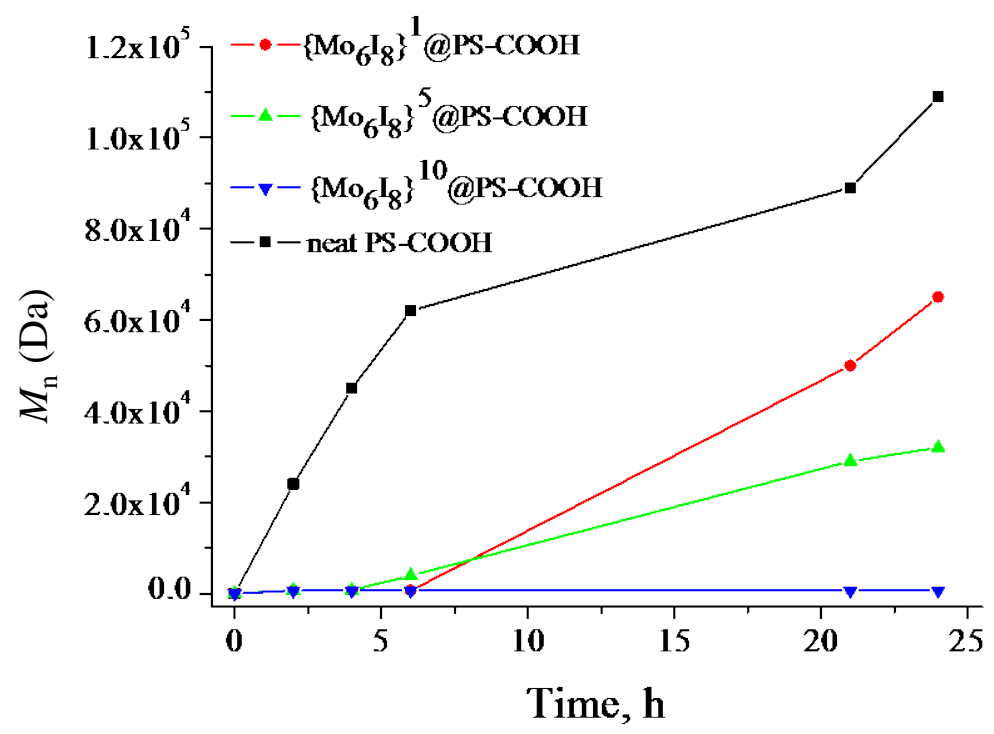

Figure 1. Molecular weight for neat PS-COOH and $\left\{\mathrm{Mo}_{6} \mathrm{I}_{8}\right\} @ P S-C O O H$ materials with different cluster content

Table 1. Final conversions of monomer in the copolymerisation experiments carried out with and without Mo6 cluster complexes as determined by ${ }^{1} \mathrm{H}$ NMR spectroscopy and Number-average molar mass $\left(M_{\mathrm{n}}\right)$ and dispersity index $(\nexists)$ determined by GPC in THF. Reaction time was 24 hours.

\begin{tabular}{|c|c|c|c|c|}
\hline $\begin{array}{c}\text { Matrix or } \\
\text { Cluster@Matrix }\end{array}$ & $\begin{array}{c}\text { Cluster } \\
\text { content }(n) \text {, } \\
\%\end{array}$ & $M_{\mathrm{n}}, \mathrm{kDa}$ & 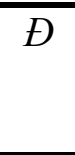 & $\begin{array}{l}\text { Conversion } \\
\text { (NMR), \% }\end{array}$ \\
\hline neat PS-COOH & 0 & 110 & 2.5 & 85 \\
\hline $\multirow{3}{*}{\mathrm{Mo}_{6} \mathrm{Cl}_{8}}^{n} @ \mathrm{PS}-\mathrm{COOH}$ & 1 & 68 & 2 & 40 \\
\hline & 5 & 18 & 2 & 33 \\
\hline & 10 & 0.6 & 1 & 18 \\
\hline $\multirow{3}{*}{\mathrm{Mo}_{6} \mathrm{Br}_{8}}^{n} @ \mathrm{PS}-\mathrm{COOH}$ & 1 & 60 & 1.6 & 45 \\
\hline & 5 & 16 & 2 & 32 \\
\hline & 10 & 12 & 1.9 & 20 \\
\hline $\multirow{3}{*}{\mathrm{Mo}_{6} \mathrm{I}_{8}}^{n} @ \mathrm{PS}-\mathrm{COOH}$ & 1 & 65 & 1.7 & 37 \\
\hline & 5 & 32 & 1.6 & 20 \\
\hline & 10 & 0.6 & 1 & 15 \\
\hline neat PS-Py & 0 & 77 & 2.4 & 80 \\
\hline $\multirow{3}{*}{\mathrm{Mo}_{6} \mathrm{Cl}_{8}}^{n} @ P S-P y$ & 1 & 34 & 2 & 40 \\
\hline & 5 & 20 & 1.9 & 20 \\
\hline & 10 & 1.1 & 1.3 & 10 \\
\hline$\left\{\mathrm{Mo}_{6} \mathrm{Br}_{8}\right\}^{n} @$ PS-Py & 1 & 64 & 2 & 63 \\
\hline
\end{tabular}


This is the peer reviewed version of the following article: Vorotnikova, N. A., Edeleva, M. V., Kurskaya, O. G., Brylev, K. A., Shestopalov, A. M., Mironov, Y. V., Sutherland, A. J., Efremova, O. A. and Shestopalov, M. A. (2017), One-pot synthesis of \{Mo6/8\}4+-doped polystyrene microspheres via a free radical dispersion copolymerisation reaction. Polym. Int, 66: 19061912. doi:10.1002/pi.5473, which has been published in final form at http://onlinelibrary.wiley.com/doi/10.1002. This article may be used for non-commercial purposes in accordance with Wiley Terms and Conditions for Self-Archiving.

\begin{tabular}{c|cccc}
\hline & 5 & 33 & 1.7 & 25 \\
\cline { 2 - 5 } & 10 & 21 & 1.3 & 20 \\
\hline $\multirow{3}{*}{\mathrm{Mo}_{6} \mathrm{I}_{8}}^{n} @ P S-P y$ & 1 & 64 & 1.6 & 41 \\
\cline { 2 - 5 } & 5 & 10 & 2 & $<5$ \\
\cline { 2 - 5 } & 10 & 3.7 & 1.5 & $<5$ \\
\hline
\end{tabular}

\subsection{Physicochemical characterisation}

A range of techniques were employed to confirm that molybdenum cluster complexes were incorporated into the microspheres. ICP analysis showed that both $\left\{\mathrm{Mo}_{6} \mathrm{X}_{8}\right\}^{1} @ \mathrm{PS}-\mathrm{COOH}$ and $\left\{\mathrm{Mo}_{6} \mathrm{X}_{8}\right\}^{1} @ P S-P y$ do indeed contain molybdenum (Table 2S). Interestingly, $\left\{\mathrm{Mo}_{6} \mathrm{X}_{8}\right\}^{1} @ P S-P y$ samples contain noticeably more cluster than $\left\{\mathrm{Mo}_{6} \mathrm{X}_{8}\right\}^{1} @ \mathrm{PS}-\mathrm{COOH}$, i.e. pyridine-functionalised copolymers bind molybdenum clusters better than carboxyl-functionalised ones. In the reported reaction metal cluster reacts with the polymer chain donor groups. Therefore it is expectable that only a limited amount of cluster is loaded in the polymers. This amount is determined by the reaction rate of ligand metathesis reaction (i.e. substitution of $\mathrm{NO}_{3}{ }^{-}$for $\mathrm{COO}^{-}$or $\mathrm{Py}$ group) and time (which in our case was fixed to $24 \mathrm{~h}$ ). Unreacted cluster was then washed away by ethanol.

In the FTIR spectra of the microspheres the vibration signals of the nitrato ligands of the starting clusters were not detected, which suggests the successful substitution of the ligands by the donor groups of the functionalised monomers (Figure 12S). UV/Vis diffuse reflectance spectra of the samples doped with the molybdenum clusters demonstrate enhancement of absorption within the visible region. In this region there is an increased absorbance in the blue diapason of the spectra in the order $\mathrm{Cl}<\mathrm{Br}<\mathrm{I}$ (Figure 2). These observations are in agreement with the general trend found within the family of octahedral molybdenum cluster complexes based on $\left\{\mathrm{Mo}_{6} \mathrm{X}_{8}\right\}^{4+}$ cores. ${ }^{19,43,44}$
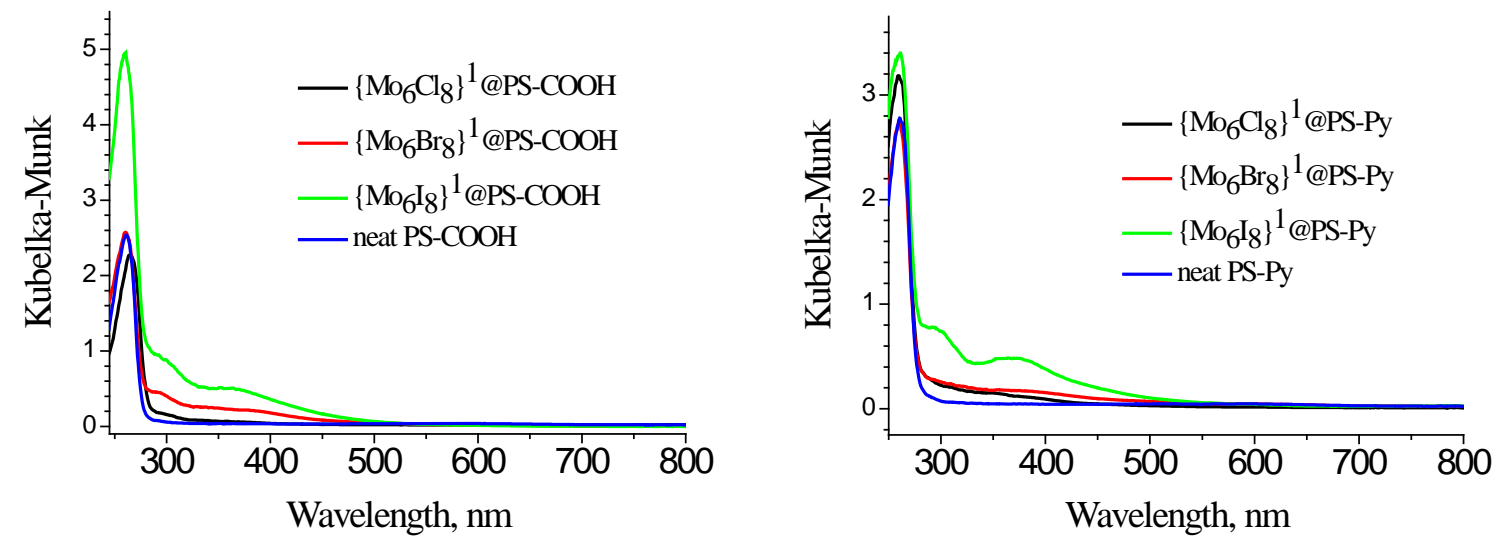
This is the peer reviewed version of the following article: Vorotnikova, N. A., Edeleva, M. V., Kurskaya, O. G., Brylev, K. A., Shestopalov, A. M., Mironov, Y. V., Sutherland, A. J., Efremova, O. A. and Shestopalov, M. A. (2017), One-pot synthesis of \{Mo6/8\}4+-doped polystyrene microspheres via a free radical dispersion copolymerisation reaction. Polym. Int, 66: 19061912. doi:10.1002/pi.5473, which has been published in final form at http://onlinelibrary.wiley.com/doi/10.1002. This article may be used for non-commercial purposes in accordance with Wiley Terms and Conditions for Self-Archiving.

Figure 2. Ultraviolet/visible diffuse reflectance spectra of $\left\{\mathrm{Mo}_{6} \mathrm{X}_{8}\right\}^{1} @ \mathrm{PS}-\mathrm{COOH}$ and neat PS$\mathrm{COOH}$ (left) or $\left\{\mathrm{Mo}_{6} \mathrm{X}_{8}\right\}^{1} @ P S-P y$ and neat PS-Py (right)

According to TEM imaging, the particles have spherical morphologies with sub-micron sizes mainly in the range of 400-700 nm (Figures 3 and 13S), while the electron energy-loss spectroscopy (EELS) confirmed the uniform distribution of the clusters within the copolymer matrices. DLS data (Table 3S) show that the hydrodynamic size range of the particles is in the range of $\sim 600-1400 \mathrm{~nm}$, while dispersity index values demonstrate a relatively broad size distribution. This broad size distribution is likely due to both the presence of polar (hydrophilic) monomers and the incorporation of the charged cluster species into the copolymer.

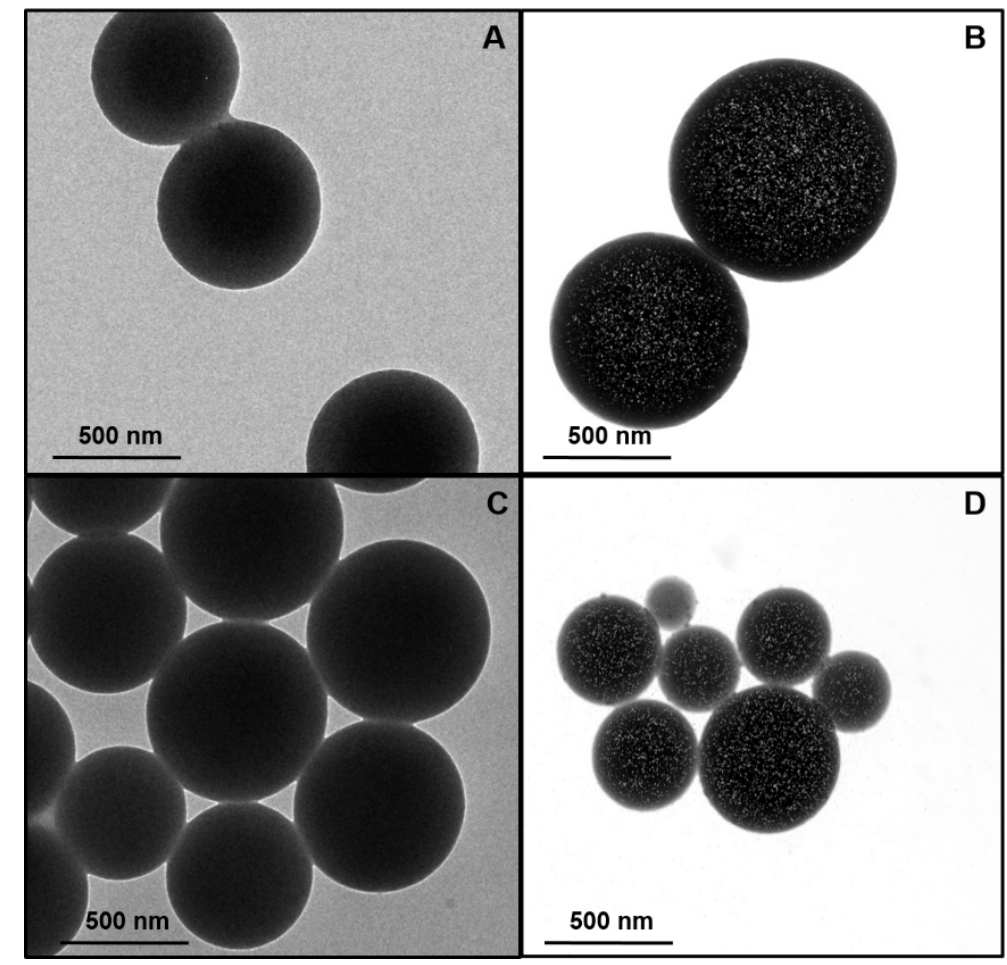

Figure 3. Representative TEM images of neat PS-COOH (A) and neat PS-Py (C), $\left\{\mathrm{Mo}_{6} \mathrm{I}_{8}\right\}^{1} @ \mathrm{PS}-$ $\mathrm{COOH}(\mathrm{B})$ and $\left\{\mathrm{Mo}_{6} \mathrm{I}_{8}\right\}^{1} @ \mathrm{PS}-\mathrm{Py}(\mathrm{D})$. White dots visible in B and D show the molybdenum distribution obtained from electron energy-loss spectroscopy

\subsection{Luminescence measurements}

Emission spectra of the dried powdered samples are presented in Figures 4 and 5, while photophysical characteristics: emission maximum wavelength $\left(\lambda_{\mathrm{em}}\right)$, photoluminescence 
This is the peer reviewed version of the following article: Vorotnikova, N. A., Edeleva, M. V., Kurskaya, O. G., Brylev, K. A., Shestopalov, A. M., Mironov, Y. V., Sutherland, A. J., Efremova, O. A. and Shestopalov, M. A. (2017), One-pot synthesis of \{Mo6/8\}4+-doped polystyrene microspheres via a free radical dispersion copolymerisation reaction. Polym. Int, 66: 19061912. doi:10.1002/pi.5473, which has been published in final form at http://onlinelibrary.wiley.com/doi/10.1002. This article may be used for non-commercial purposes in accordance with Wiley Terms and Conditions for Self-Archiving.

quantum yields $\left(\Phi_{\mathrm{em}}\right)$ and emission lifetimes $\left(\tau_{\mathrm{em}}\right)$ with the corresponding amplitudes $(A)$ of $\left\{\mathrm{Mo}_{6} \mathrm{X}_{8}\right\}^{1} @ \mathrm{PS}-\mathrm{COOH}$ and $\left\{\mathrm{Mo}_{6} \mathrm{X}_{8}\right\}^{1} @ \mathrm{PS}-\mathrm{Py}$ are given in Table 2 along with those of precursors $\left(\mathrm{Bu}_{4} \mathrm{~N}\right)_{2}\left[\left\{\mathrm{Mo}_{6} \mathrm{X}_{8}\right\}\left(\mathrm{NO}_{3}\right)_{6}\right]$ for the sake of comparison. Emission decay profiles of $\left\{\mathrm{Mo}_{6} \mathrm{Br}_{8}\right\}^{1} @ \mathrm{PS}-\mathrm{COOH}$ and $\left\{\mathrm{Mo}_{6} \mathrm{I}_{8}\right\}^{1} @ \mathrm{PS}-\mathrm{COOH}$ are presented in Figures 14S and 15S. One can notice that the luminescence properties of microspheres $\left\{\mathrm{Mo}_{6} \mathrm{X}_{8}\right\}^{1} @ \mathrm{PS}-\mathrm{Py}$ are noticeably weaker than those of $\left\{\mathrm{Mo}_{6} \mathrm{X}_{8}\right\}^{1} @ \mathrm{PS}-\mathrm{COOH}$. This is likely due to the coordination of pyridine ligands to molybdenum cluster. Indeed, DFT calculations undertaken earlier for $\left[\left\{\mathrm{Mo}_{6} \mathrm{Cl}_{8}\right\}(\mathrm{Py})_{6}\right]^{4+}$ by R. Ramirez-Tagle et al. ${ }^{45}$ demonstrated significant contribution of the axial pyridine ligands to the LUMO, which is different from some other luminescent $\left\{\mathrm{Mo}_{6} \mathrm{X}_{8}\right\}^{4+}$ complexes, where the LUMO arises mostly from the cluster core. The authors of the calculations therefore concluded that the presence of pyridine ligands in the ligand environment of the molybdenum cluster core would switch off luminescence. ${ }^{45}$ The recent study by Akagi et al. further concludes that the electron density in the $\left\{\mathrm{Mo}_{6} \mathrm{X}_{8}\right\}^{4+}$ cluster core is the most important factor determining the photophysical properties of these clusters. ${ }^{21}$ Pyridine ligands are strong electron donors, while acrylate groups being residues of a medium strength acid have more pronounced electron-withdrawing properties, but not as strong as that of residues of the strong oxygenated acids (e.g. sulfonates, nitrates and fluorinated acids). High electron density in the cluster core in the case of pyridine based materials effectively results in the absence of luminescence, while the electron-withdrawing nature of the carboxylate group gives rise to luminescent materials.

The luminescence quantum yield of $\left\{\mathrm{Mo}_{6} \mathrm{Cl}_{8}\right\}^{1} @ \mathrm{PS}-\mathrm{COOH}$ was too low to be detected. This is in agreement with the earlier studies. ${ }^{6}$ Indeed, from all known $\left\{\mathrm{Mo}_{6} \mathrm{Cl}_{8}\right\}^{4+}$ complexes only $\left[\left\{\mathrm{Mo}_{6} \mathrm{Cl}_{8}\right\} \mathrm{Cl}_{6}\right]^{2-}$ revealed significant photoluminescence quantum yield. ${ }^{46}$ To our regret, we also observed a considerable reduction of photoluminescence quantum yields for $\left\{\mathrm{Mo}_{6} \mathrm{Br}_{8}\right\}^{4+}$ and $\left\{\mathrm{Mo}_{6} \mathrm{I}_{8}\right\}^{4+}$ in the case of the PS-COOH matrix in comparison with the starting nitrato complexes $\left[\left\{\mathrm{Mo}_{6} \mathrm{X}_{8}\right\}\left(\mathrm{NO}_{3}\right)_{6}\right]^{2-}(\mathrm{X}=\mathrm{Br}$ or I) (Table 2), while the luminescence quantum yields reported for carboxylate hexamolybdenum complexes, in particular for $\left\{\mathrm{Mo}_{6} \mathrm{I}_{8}\right\}^{4+}$-based ones, lay in the ranges of $0.13-0.36$ for solid samples and $0.48-0.67$ for deaerated acetonitrile solutions. ${ }^{20}$ Such reduction may be attributed to partial solvolysis of molybdenum cluster complexes during the copolymerisation. The shifts of emission maxima peaks is likely due to the change of the coordination environment of the cluster cores as has been observed earlier for other matrices. $^{5,6,14}$ 
This is the peer reviewed version of the following article: Vorotnikova, N. A., Edeleva, M. V., Kurskaya, O. G., Brylev, K. A., Shestopalov, A. M., Mironov, Y. V., Sutherland, A. J., Efremova, O. A. and Shestopalov, M. A. (2017), One-pot synthesis of \{Mo6/8\}4+-doped polystyrene microspheres via a free radical dispersion copolymerisation reaction. Polym. Int, 66: 19061912. doi:10.1002/pi.5473, which has been published in final form at http://onlinelibrary.wiley.com/doi/10.1002. This article may be used for non-commercial purposes in accordance with Wiley Terms and Conditions for Self-Archiving.

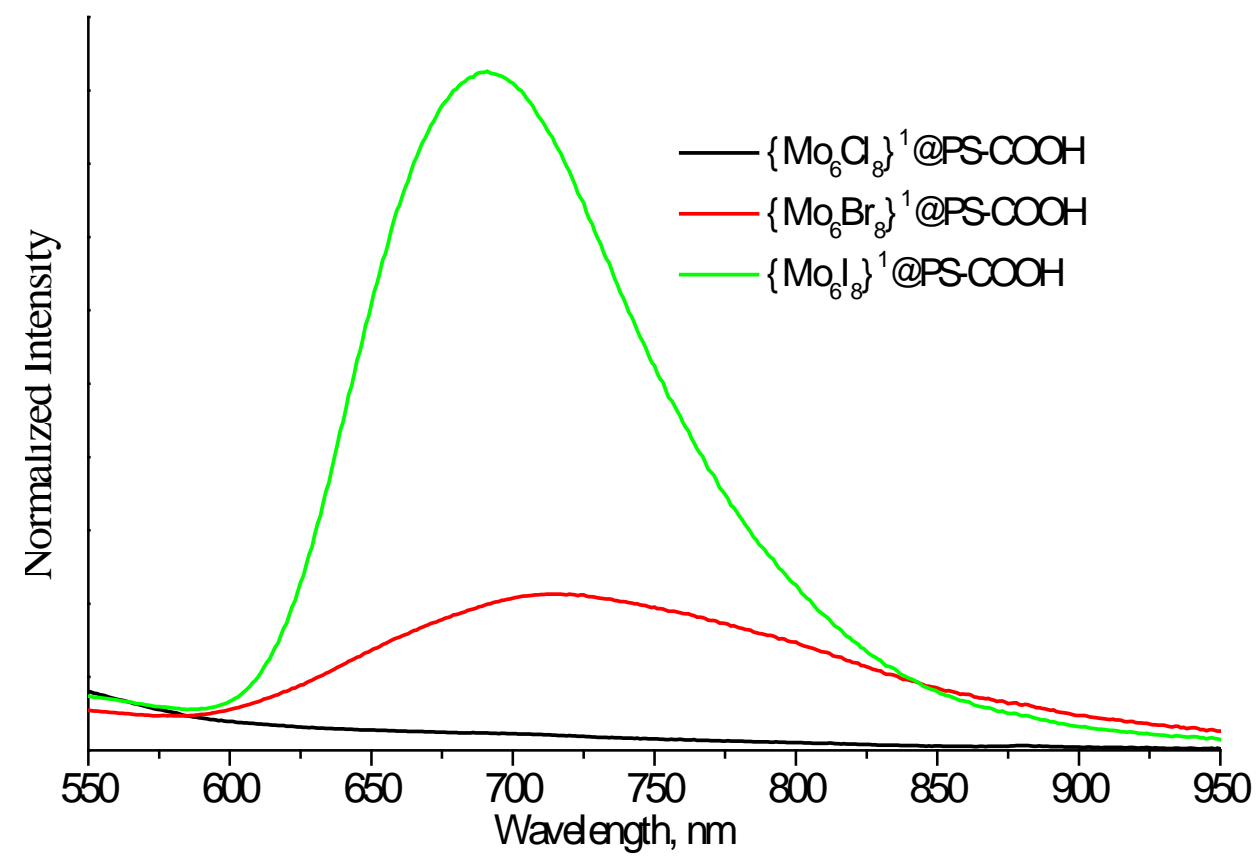

Figure 4. Luminescence spectra of $\left\{\mathrm{Mo}_{6} \mathrm{X}_{8}\right\}^{1} @ \mathrm{PS}-\mathrm{COOH}$ materials. The samples were placed between two non-fluorescent glass plates and excited by 355-nm laser pulses. The measurements were carried out at $298 \mathrm{~K}$.

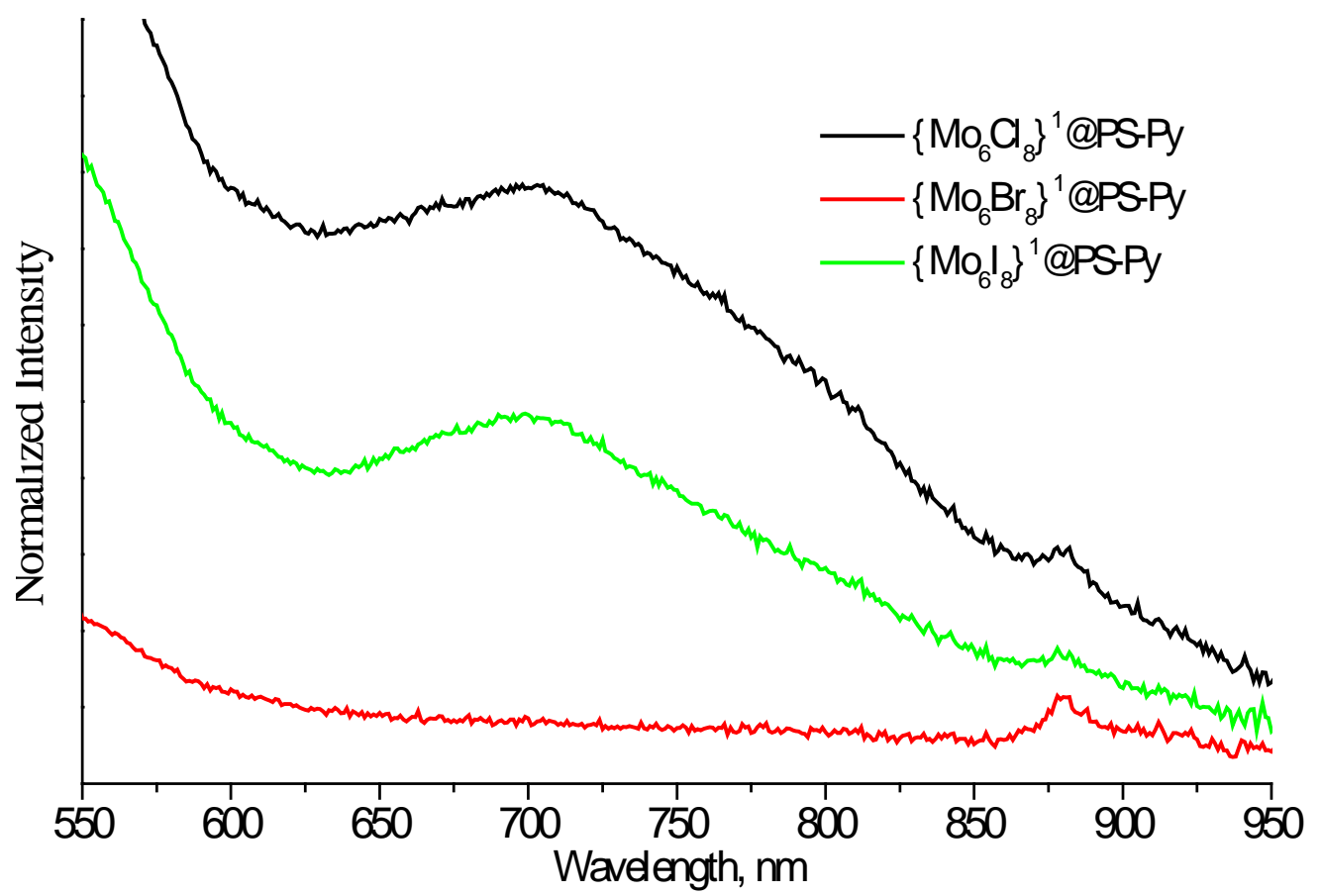

Figure 5. Luminescence spectra of $\left\{\mathrm{Mo}_{6} \mathrm{X}_{8}\right\}^{1} @ P S-P y$ materials. The samples were placed between two non-fluorescent glass plates and excited by 355-nm laser pulses. The measurements were carried out at $298 \mathrm{~K}$. 
This is the peer reviewed version of the following article: Vorotnikova, N. A., Edeleva, M. V., Kurskaya, O. G., Brylev, K. A., Shestopalov, A. M., Mironov, Y. V., Sutherland, A. J., Efremova, O. A. and Shestopalov, M. A. (2017), One-pot synthesis of \{Mo6/8\}4+-doped polystyrene microspheres via a free radical dispersion copolymerisation reaction. Polym. Int, 66: 19061912. doi:10.1002/pi.5473, which has been published in final form at http://onlinelibrary.wiley.com/doi/10.1002. This article may be used for non-commercial purposes in accordance with Wiley Terms and Conditions for Self-Archiving.

Table 2. Luminescence data for $\left[\left\{\mathrm{Mo}_{6} \mathrm{X}_{8}\right\}\left(\mathrm{NO}_{3}\right)_{6}\right]^{2-}$ and the hybrid materials $\left\{\mathrm{Mo}_{6} \mathrm{X}_{8}\right\}^{1} @ \mathrm{PS}-$ $\mathrm{COOH}$ and $\left\{\mathrm{Mo}_{6} \mathrm{X}_{8}\right\}^{1} @ \mathrm{PS}-\mathrm{Py}(\mathrm{X}=\mathrm{Cl}, \mathrm{Br}$ or $\mathrm{I}) . \lambda_{\mathrm{em}}$ is an emission maximum wavelength; $\tau_{\mathrm{em}}$ are the photoluminescence lifetimes with the corresponding amplitudes $(A)$ for the photoluminescence decay equation, where intensity $(I)$ of photoluminescence $v s$ time is expressed as $I=I_{0} \sum_{i=1}^{n} A_{i} \exp \left(-\frac{t}{\tau_{i}}\right) ; \Phi_{\mathrm{em}}$ is photoluminescence quantum yield.

\begin{tabular}{|c|c|c|c|}
\hline Sample & $\lambda_{\mathrm{em}}, \mathrm{nm}$ & $\tau_{\mathrm{em}}, \mu \mathrm{s}(A)$ & $\Phi_{\mathrm{em}}$ \\
\hline$\left(\mathrm{Bu}_{4} \mathrm{~N}\right)_{2}\left[\left\{\mathrm{Mo}_{6} \mathrm{Cl}_{8}\right\}\left(\mathrm{NO}_{3}\right)_{6}\right]^{6}$ & $\sim 765$ & $\begin{aligned} \tau_{1} & =17(0.14) \\
\tau_{2} & =9.3(0.02) \\
\tau_{3} & =1.9(0.84)\end{aligned}$ & $<0.005$ \\
\hline$\left(\mathrm{Bu}_{4} \mathrm{~N}\right)_{2}\left[\left\{\mathrm{Mo}_{6} \mathrm{Br} 8\right\}\left(\mathrm{NO}_{3}\right)_{6}\right]^{6}$ & $\sim 785$ & $\begin{aligned} \tau_{1} & =19(0.25) \\
\tau_{2} & =11(0.20) \\
\tau_{3} & =0.9(0.55)\end{aligned}$ & $<0.01$ \\
\hline$\left(\mathrm{Bu}_{4} \mathrm{~N}\right)_{2}\left[\left\{\mathrm{Mo}_{6} \mathrm{I}_{8}\right\}\left(\mathrm{NO}_{3}\right)_{6}\right]^{5}$ & $\sim 666$ & $\begin{array}{l}\tau_{1}=96(0.71) \\
\tau_{2}=26(0.29)\end{array}$ & 0.26 \\
\hline$\left\{\mathrm{Mo}_{6} \mathrm{Cl}_{8}\right\}^{1} @ \mathrm{PS}-\mathrm{COOH}$ & - & - & - \\
\hline$\left\{\mathrm{Mo}_{6} \mathrm{Br}_{8}\right\}^{1} @ \mathrm{PS}-\mathrm{COOH}$ & $\sim 715$ & $\begin{array}{c}\tau_{1}=42.6(0.03 \\
\tau_{2}=8.0(0.07) \\
\tau_{3}=0.51(0.90)\end{array}$ & $<0.005$ \\
\hline$\left\{\mathrm{Mo}_{6} \mathrm{I}_{8}\right\}^{1} @ \mathrm{PS}-\mathrm{COOH}$ & $\sim 690$ & $\begin{array}{l}\tau_{1}=70.1(0.12) \\
\tau_{2}=17.9(0.31) \\
\tau_{3}=2.06(0.57)\end{array}$ & $<0.005$ \\
\hline$\left\{\mathrm{Mo}_{6} \mathrm{Cl}_{8}\right\}^{1} @ \mathrm{PS}-\mathrm{Py}$ & - & - & - \\
\hline$\left\{\mathrm{Mo}_{6} \mathrm{Br}_{8}\right\}^{1} @ \mathrm{PS}-\mathrm{Py}$ & $\sim 700$ & - & - \\
\hline$\left\{\mathrm{Mo}_{6} \mathrm{I}_{8}\right\}^{1} @ \mathrm{PS}-\mathrm{Py}$ & $\sim 700$ & - & - \\
\hline
\end{tabular}

\subsection{Cellular toxicity studies}

Since materials based on octahedral hexanuclear cluster complexes have high potential for a range of biological applications including optical or X-ray bioimaging ${ }^{7,47-51}$ and photodynamic 
This is the peer reviewed version of the following article: Vorotnikova, N. A., Edeleva, M. V., Kurskaya, O. G., Brylev, K. A., Shestopalov, A. M., Mironov, Y. V., Sutherland, A. J., Efremova, O. A. and Shestopalov, M. A. (2017), One-pot synthesis of \{Mo6/8\}4+-doped polystyrene microspheres via a free radical dispersion copolymerisation reaction. Polym. Int, 66: 19061912. doi:10.1002/pi.5473, which has been published in final form at http://onlinelibrary.wiley.com/doi/10.1002. This article may be used for non-commercial purposes in accordance with Wiley Terms and Conditions for Self-Archiving.

therapy, ${ }^{15}, 28,52$ we have recently launched a thorough evaluation of toxicity of Mo6-based compounds and materials., ${ }^{6,28,28}$ Here, we have studied toxicity of the material $\left\{\mathrm{Mo}_{6} \mathrm{I}_{8}\right\}^{1} @ \mathrm{PS}-$ $\mathrm{COOH}$, which showed the highest emission brightness (Figure 4), and neat PS-COOH microspheres on human epidermoid larynx carcinoma (Hep-2) cells within a broad range of concentrations $(0.003-3.25 \mathrm{mg} / \mathrm{mL})$. These studies were based on a standard colorimetric cytotoxicity assay using 3-(4,5-dimethylthiazolyl-2)-2,5-diphenyltetrazolium bromide (MTT) assay. Percentages of metabolically active cells after incubation with the microspheres for $48 \mathrm{~h}$ against the negative control (i.e. cells incubated without the microspheres) are given in Figure 6. The MTT test revealed that both neat and molybdenum cluster-doped materials did not show a significant depressive effect on Hep-2 cells proliferation across the whole concentration range. Surprisingly, the results displayed that the cluster-based material was somewhat less toxic than the neat copolymer PS-COOH. Specifically at the highest incubation concentration the viability of the cells in the presence of the cluster-doped material was $95 \%$, while it was about $80 \%$ in the presence of the neat copolymer. Although we cannot explain this peculiar observation with certainty, we suggest that the reasons for that could be both the difference of the size (Table 3S) or even zeta potential of the materials, namely the effect of these parameters on the cellular internalisation of the material. Due to the exceptionally low toxicity of both materials, the $\mathrm{IC}_{50}$ doses were not established.

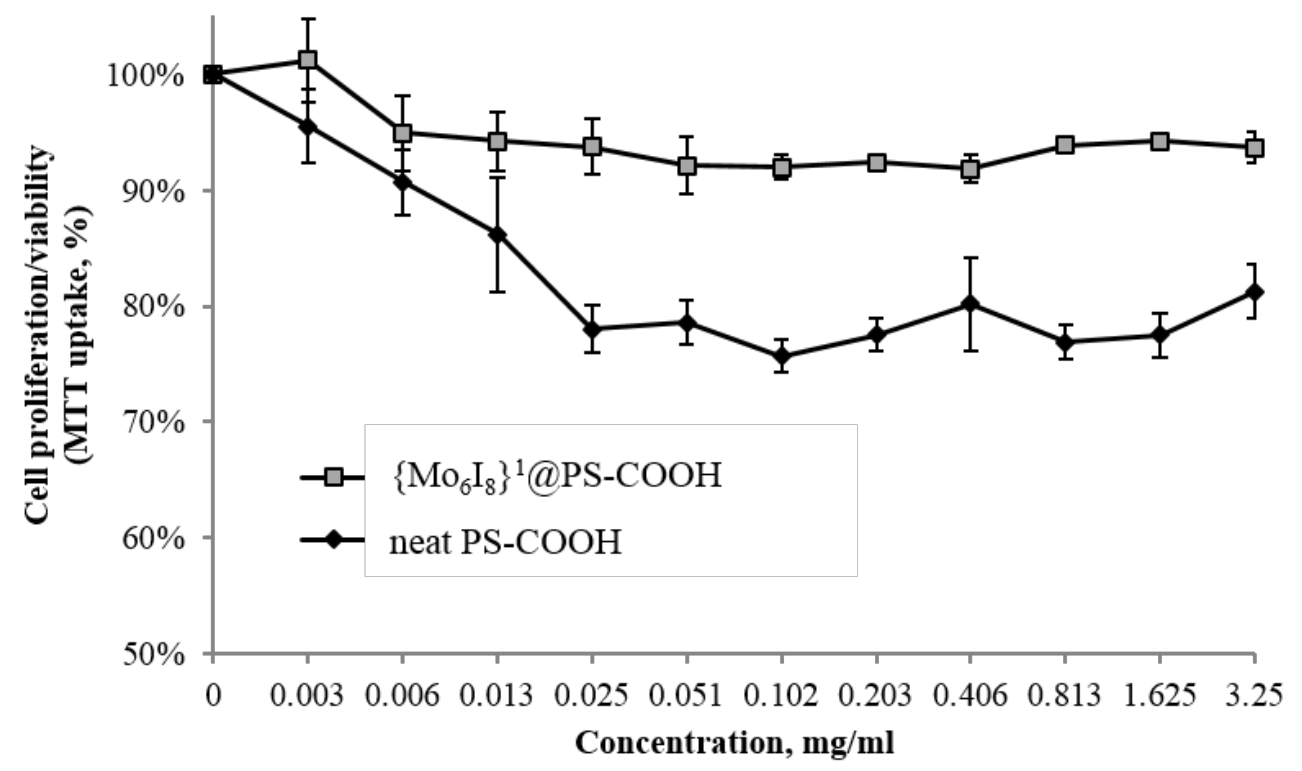

Figure 6. MTT data for the most luminescent $\left\{\mathrm{Mo}_{6} \mathrm{I}_{8}\right\}^{1} @ \mathrm{PS}-\mathrm{COOH}$ material and for the neat PS- 
This is the peer reviewed version of the following article: Vorotnikova, N. A., Edeleva, M. V., Kurskaya, O. G., Brylev, K. A., Shestopalov, A. M., Mironov, Y. V., Sutherland, A. J., Efremova, O. A. and Shestopalov, M. A. (2017), One-pot synthesis of \{Mo6/8\}4+-doped polystyrene microspheres via a free radical dispersion copolymerisation reaction. Polym. Int, 66: 19061912. doi:10.1002/pi.5473, which has been published in final form at http://onlinelibrary.wiley.com/doi/10.1002. This article may be used for non-commercial purposes in accordance with Wiley Terms and Conditions for Self-Archiving.

\section{Conclusion}

The major conclusion of this work is that photoluminescent spherical polystyrene particles doped with octahedral molybdenum cluster can indeed be obtained in a facile one-pot dispersion copolymerisation reaction. However, there are at least two challenges associated with this process: 1) the presence of reactive (labile) molybdenum cluster complexes at high concentrations inhibits/suppresses free-radical copolymerisation; 2) ligand substitution significantly changes the photophysical properties of hexamolybdenum cluster complexes. Specifically, we have demonstrated that binding hexamolybdenum clusters by the carboxylated copolymer matrix results in photoluminescent materials, while the corresponding pyridinefunctionalised copolymer switches off photoluminescence of the cluster. The latter finding is in agreement with recent studies of the effects of the $\mathrm{pK}_{\mathrm{a}} \mathrm{s}$ of apical ligands on the photoluminescence properties of molybdenum clusters, i.e. the higher $\mathrm{pK}_{\mathrm{a}}(\mathrm{LH})$ value the lower quantum yield of the corresponding cluster complex $\left[\left\{\mathrm{Mo}_{6} \mathrm{X}_{8}\right\} \mathrm{L}_{6}\right]^{2-} \cdot 20$

\section{Acknowledgements}

This work was supported by the Grant of the President of the Russian Federation [grant number MK-180.2017.3]. The syntheses of cluster complexes as well as their characterization in this work were supported by RFBR according to the research project №17-03-00140. K. A. Brylev gratefully thanks Prof. N. Kitamura (Hokkaido University) for the opportunity to study the luminescence properties. We also thank Dr. Inna A. Pyshnaya from the core facility in ICBFM SB RAS for DLS measurements and to the Microscopic Centre of the Siberian Branch of the Russian Academy of Sciences for granting access to microscopic equipment in ICG SB RAS.

\section{References}

1 Garreau A, Massuyeau F, Cordier S, Molard Y, Gautron E, Bertoncini P et al., ACS Nano 7:2977-2987 (2013).

2 Efremova OA, Brylev KA, Vorotnikov YA, Vejsadova L, Shestopalov MA, Chimonides GF et al., J Mater Chem C 4:497-503 (2016).

3 Efremova OA, Brylev KA, Kozlova O, White MS, Shestopalov MA, Kitamura N et al., $J$ Mater Chem C 2:8630-8638 (2014).

4 Amela-Cortes M, Paofai S, Cordier S, Folliot H and Molard Y, Chem Commun 51:8177-8180 (2015). 
This is the peer reviewed version of the following article: Vorotnikova, N. A., Edeleva, M. V., Kurskaya, O. G., Brylev, K. A., Shestopalov, A. M., Mironov, Y. V., Sutherland, A. J., Efremova, O. A. and Shestopalov, M. A. (2017), One-pot synthesis of \{Mo6/8\}4+-doped polystyrene microspheres via a free radical dispersion copolymerisation reaction. Polym. Int, 66: 19061912. doi:10.1002/pi.5473, which has been published in final form at http://onlinelibrary.wiley.com/doi/10.1002. This article may be used for non-commercial purposes in accordance with Wiley Terms and Conditions for Self-Archiving.

5 Efremova OA, Shestopalov MA, Chirtsova NA, Smolentsev AI, Mironov YV, Kitamura N et al., Dalton Trans 43:6021-6025 (2014).

6 Vorotnikova NA, Efremova OA, Tsygankova AR, Brylev KA, Edeleva MV, Kurskaya OG et al., Polym Adv Technol 27:922-928 (2016).

7 Kirakci K, Kubat P, Fejfarova K, Martincik J, Nikl M and Lang K, Inorg Chem 55:803-809 (2016).

8 Amela-Cortes M, Garreau A, Cordier S, Faulques E, Duvail JL and Molard Y, J Mater Chem C 2:1545-1552 (2014).

9 Jackson JA, Newsham MD, Worsham C and Nocera DG, Chem Mater 8:558-564 (1996).

10 Molard Y, Dorson F, Brylev KA, Shestopalov MA, Le Gal Y, Cordier S et al., Chem Eur J 16:5613-5619 (2010).

11 Kirakci K, Kubat P, Dusek M, Fejfarova K, Sicha V, Mosinger J et al., Eur J Inorg Chem:3107-3111 (2012).

12 Robin M, Kuai WL, Amela-Cortes M, Cordier S, Molard Y, Mohammed-Brahim T et al., ACS Appl Mater Inter 7:21975-21984 (2015).

13 Amela-Cortes M, Molard Y, Paofai S, Desert A, Duvail JL, Naumov NG et al., Dalton Trans 45:237-245 (2016).

14 Svezhentseva EV, Solovieva AO, Vorotnikov YA, Kurskaya OG, Brylev KA, Tsygankova AR et al., New J Chem 41:1670-1676 (2017).

15 Beltran A, Mikhailov M, Sokolov MN, Perez-Laguna V, Rezusta A, Revillo MJ et al., $J$ Mater Chem B 4:5975-5979 (2016).

16 Sokolov MN, Mihailov MA, Peresypkina EV, Brylev KA, Kitamura N and Fedin VP, Dalton Trans 40:6375-6377 (2011).

17 Kirakci K, Fejfarova K, Kucerakova M and Lang K, Eur J Inorg Chem 2014:2331-2336 (2014).

18 Kirakci K, Sicha V, Holub J, Kubat P and Lang K, Inorg Chem 53:13012-13018 (2014).

19 Efremova OA, Vorotnikov YA, Brylev KA, Vorotnikova NA, Novozhilov IN, Kuratieva NV et al., Dalton Trans 45:15427-15435 (2016).

20 Mikhailov MA, Brylev KA, Abramov PA, Sakuda E, Akagi S, Ito A et al., Inorg Chem 55:8437-8445 (2016).

21 Akagi S, Fujii S, Horiguchi T and Kitamura N, J Clust Sci 28:757-772 (2017).

22 Eggeling C, Volkmer A and Seidel CAM, Chemphyschem 6:791-804 (2005). 
This is the peer reviewed version of the following article: Vorotnikova, N. A., Edeleva, M. V., Kurskaya, O. G., Brylev, K. A., Shestopalov, A. M., Mironov, Y. V., Sutherland, A. J., Efremova, O. A. and Shestopalov, M. A. (2017), One-pot synthesis of \{Mo6/8\}4+-doped polystyrene microspheres via a free radical dispersion copolymerisation reaction. Polym. Int, 66: 19061912. doi:10.1002/pi.5473, which has been published in final form at http://onlinelibrary.wiley.com/doi/10.1002. This article may be used for non-commercial purposes in accordance with Wiley Terms and Conditions for Self-Archiving.

23 Vogelsang J, Kasper R, Steinhauer C, Person B, Heilemann M, Sauer M et al., Angewandte Chemie-International Edition 47:5465-5469 (2008).

24 Resch-Genger U, Grabolle M, Cavaliere-Jaricot S, Nitschke R and Nann T, Nature Methods 5:763-775 (2008).

25 Evtushok DV, Melnikov AR, Vorotnikova NA, Ryadun AA, Kuratieva NV, Kozyr KV et al., Dalton Trans:DOI: 10.1039/C1037DT01919J (2017).

26 Winnik FM and Maysinger D, Acc Chem Res 46:672-680 (2013).

27 Rizvi SB, Yang SY, Green M, Keshtgar M and Seifalian AM, Bioconjugate Chem 26:23842396 (2015).

28 Solovieva AO, Vorotnikov YA, Trifonova KE, Efremova OA, Krasilnikova AA, Brylev KA et al., J Mat Chem B 4:4839-4846 (2016).

29 Braack P, Simsek MK and Preetz W, Z Anorg Allg Chem 624:375-380 (1998).

30 Chimonides GF, Behrendt JM, Chundoo E, Bland C, Hine AV, Devitt A et al., J Mater Chem B 2:7307-7315 (2014).

31 Alexander LM, Pernagallo S, Livigni A, Sanchez-Martin RM, Brickman JM and Bradley M, Mol Biosyst 6:399-409 (2010).

32 Behrendt JM, Nagel D, Chundoo E, Alexander LM, Dupin D, Hine AV et al., Plos One 8:e50713 (2013).

33 Zhang H-T, Yuan X-Y and Huang J-X, React Funct Polym 59:23-31 (2004).

34 Zhang H, Huang H, lv R and Chen M, Colloid Surface 253:217-221 (2005).

35 Hong-Tao Z, Rui L and Min C, Chem J Chin Univ 25:366-371 (2004).

36 Yang W, Hu J, Tao Z, Li L, Wang C and Fu S, Colloid Polym Sci 277:446-451 (1999).

37 Han H, Hong CK, Hong J, Park DW and Shim SE, J Appl Polym Sci 111:2900-2907 (2009).

38 Yang W, Yang D, Hu J, Wang C and Fu S, J Polym Sci A1 39:555-561 (2001).

39 Wizel S, Margel S, Gedanken A, Rojas TC, Fernandez A and Prozorov R, J Mater Res 14:3913-3920 (1999).

40 Maverick AW and Gray HB, J Am Chem Soc 103:1298-1300 (1981).

41 Nocera DG and Gray HB, J Am Chem Soc 106:824-825 (1984).

42 Kirakci K, Kubat P, Langmaier J, Polivka T, Fuciman M, Fejfarova K et al., Dalton Trans 42:7224-7232 (2013).

43 Vorotnikov YA, Efremova OA, Novozhilov IN, Yanshole VV, Kuratieva NV, Brylev KA et al., J Mol Struct 1134:237-243 (2017). 
This is the peer reviewed version of the following article: Vorotnikova, N. A., Edeleva, M. V., Kurskaya, O. G., Brylev, K. A., Shestopalov, A. M., Mironov, Y. V., Sutherland, A. J., Efremova, O. A. and Shestopalov, M. A. (2017), One-pot synthesis of \{Mo6/8\}4+-doped polystyrene microspheres via a free radical dispersion copolymerisation reaction. Polym. Int, 66: 19061912. doi:10.1002/pi.5473, which has been published in final form at http://onlinelibrary.wiley.com/doi/10.1002. This article may be used for non-commercial purposes in accordance with Wiley Terms and Conditions for Self-Archiving.

44 Vorotnikov YA, Efremova OA, Vorotnikova NA, Brylev KA, Edeleva MV, Tsygankova AR et al., RSC Advances 6:43367-43375 (2016).

45 Ramirez-Tagle R and Arratia-Pérez R, Chem Phys Lett 475:232-234 (2009).

46 Zhao Y and Lunt RR, Adv Energy Mater 3:1143-1148 (2013).

47 Krasilnikova AA, Shestopalov MA, Brylev KA, Kirilova IA, Khripko OP, Zubareva KE et al., J Inorg Biochem 144:13-17 (2015).

48 Krasilnikova AA, Solovieva AO, Trifonova KE, Brylev KA, Ivanov AA, Kim S-J et al., Contrast Media Mol Imaging 11:459-466 (2016).

49 Neaime C, Amela-Cortes M, Grasset F, Molard Y, Cordier S, Dierre B et al., Phys Chem Chem Phys 18:30166-30173 (2016).

50 Krasilnikova AA, Solovieva AO, Ivanov AA, Trifonova KE, Pozmogova TN, Tsygankova AR et al., Nanomedicine NBM 13:755-763 (2017).

51 Elistratova JG, Brylev KA, Solovieva AO, Pozmogova TN, Mustafina AR, Shestopalova LV et al., J Photochem Photobiol A 340:46-52 (2017).

52 Shestopalov MA, Zubareva KE, Khripko OP, Khripko YI, Solovieva AO, Kuratieva NV et al., Inorg Chem 53:9006-9013 (2014).

53 Cheplakova AM, Solovieva AO, Pozmogova TN, Vorotnikov YA, Brylev KA, Vorotnikova NA et al., J Inorg Biochem 166:100-107 (2017). 